\title{
キャピラリ微小セル法による材料表面評価
}

\author{
伏見 公志*，坂入 正敏*，幅崎 浩樹* \\ *北海道大学 大学院工学研究科 (⿳060-8628 北海道札幌市北区北十三条西 8 丁目)
}

\section{Evaluation of Materials Surface Using Capillary Micro-cell Technique}

Koji FUSHIMI*, Masatoshi SAKAIRI* and Hiroki HABAZAKI*

*Graduate School of Engineering, Hokkaido University (Kita-13 Jo, Nishi-8 Chome, Kita-ku, Sapporo-shi, Hokkaido 060-8628)

Keywords : Capillary, Micro-electrochemistry, Micro-cell, Droplet, Local Analysis

\section{1.はじめに}

ガラスなどの小径管, いわゆるキャピラリを用いて微小電 気化学セルを形成する「キャピラリ微小セル法」は, 試料表 面上の局所における電気化学に適しており, 各種材料表面の 微小評価法としてのみならず, 電気化学微細加工法として注 目を浴びている。ここでは, キャピラリ微小セル法の原理と 特徵, 用いる際の注意事項を述べるとともに, 材料表面評価 に適用した実例，応用例について解説する。

\section{2. 微小領域材料表面に対する電気化学測定の必要性}

電気化学法は, めっきや電鋳のように材料開発の直接的な 手段であると同時に, 耐食性や界面特性など材料の実用に際 し重要な情報を得るための測定・評価法として広く用いられ ている。電気化学測定から得られる示強性の物理量は, 界面 構造の解析に不可欠となっている。たとえば, 電極電位は試 料電極界面の電気化学活性種の活量比や化学ポテンシャルな どに関する情報を与える。一方, 電極に通じる電流は, 示量 性物理量であるが, 試料電極面積に比例して変化する。しか し, 前者を後者で除した物理量, すなわち電流密度は示強性 物理量であり, 界面反応の速度論を議論するため, 電極電位 と並んでよく使われる。電極反応は電極表面の法線方向に反 応物や生成物の濃度分布をもたらす不均一反応であるが，こ れら電極特性を示す示強性物理量が, 時間や座標(界面方向 の場所)によらず一定であるとき, 試料電極表面はその面方 向に均一な物性を有する “理想” 界面を構成していると見な すことができよう。これに対して “実在”界面では，電極材 料および溶液環境の物性に起因する面方向の不均一性も潜在 的, あるいは意図的に保有しているため, 電極面積を変えた (特に小さくした) とき, あるいは異なる場所の試料表面を試 料電極として用いたとき, 得られる示強性物理量はある偏差 をもってばらつく。このようなばらつきを起因とする問題は, たとえば，材料表面に存在する介在物や異常析出物，污れな どがめっき欠陥や局部腐食の起点となるように，材料開発の
至る所に顕在化している。また，傾斜組成材料は意図的に試 料物性を制御する応用例であるが, 物性のばらつきを高分解 能に把握しておくことが機能性を向上するために必定となる。 こうした背景から, 試料表面の局部・微小領域における電気 化学法, すなわち微小電気化学法による材料評価のニーズが 高まっており, 種々の微小電気化学法が開発されている。本 稿では, そのひとつであるキャピラリ微小セル法について述 ベる。

\section{3. キャピラリ微小セル法}

ここで取り上げるキャピラリは, 先端開口部の内径が 1 $\mathrm{mm}$ 以下のガラスなどでできた小径管である。電気化学法に キャピラリを取り入れること自体は, 古くから行なわれてお り, 三電極系電気化学セルの参照電極に組み合わされる Luggin-Haber 管はその代表例である。Luggin-Haber 管を 利用してセル中に二つの参照電極を設置し, 片方の管先を試 料表面上で走査する scanning reference electrode technique(SRET)では, 試料表面近傍の電位分布を与えてくれ る1)。また, キャピラリ先端に各種イオン選択膜を付与した 微小電極は電気化学センサーとして, 特に生化学の分野で利 用されている2)。このようなキャピラリを利用したさまざま な電気化学法の詳細は他で解説されている31,4)。本稿で取り 上げるキャピラリ微小セル法は, 1990 年代後半, ドイツ5) とスイス ${ }^{6)}$ の研究グループから相次いで発表された微小電気 化学法である。キャピラリ先端, すなわちセルの構造に相違 点があるものの, 他の装置構成や適用法には共通点が多いの で，並べて紹介したい。

\section{1 セルの構造}

図 1 に, キャピラリ微小セル法のセル部概略図を示す。こ こで用いられるキャピラリは, 試料電極表面に電解質溶液を 供給するための配管, 電解質溶液を保持するセル構造体の一 部, および試料表面の微小領域を試料電極として限定する シールとしての三役を担っている。キャピラリには, 一般に 先に述べたガラスの他，ポリエチレン，ポリプロピレンなど 
(a)

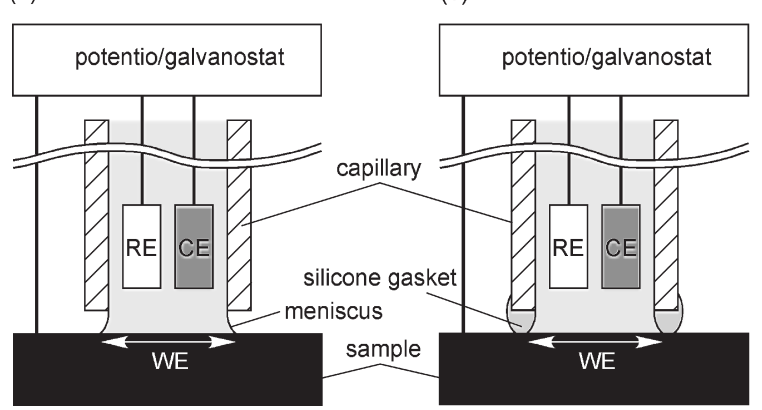

図 1 キャピラリ型微小セルの断面模式図

（a）メニスカス型，（b）ガスケット型

の絶縁性の小径管が用いられるが，後述するように対極の機 能を持たせるため白金，金，あるいはステンレス鋼製の導電 性の小径管を用いることもある。ガラス製のキャピラリの場 合，局部を加熱・延伸・切断することにより，その主胴部よ りも十分に小径な先端開口部を得ることができるため, 頻繁 に使用される。キャピラリ先端／試料電極の構造から, 以下 に述べるメニスカス型とガスケット型の 2 つに大別すること ができる。また，両型においてセル溶液を交換可能なフロー 型がある。

3. 1. 1 メニスカス型キャピラリ微小セル

微小液滴セル法(Micro-droplet cell technique) とも呼ば れるこの型は, キャピラリ先端を試料表面から一定の距離を 隔てて配置, キャピラリ先端と試料表面の間に電解質溶液の 微小な液滴を形成し，これを微小セルとする(図 1 a $)^{4), 6), 7) 。 ~}$ 試料電極は, 液滴と接する試料接触表面である。その直径は, 用いるキャピラリ先端の内径よりも外径に打抢よそ等しい。 液滴は試料とキャピラリ先端の両表面上と接する電解質溶液 の表面張力と溶液にかかる重力の釣り合いにより保持される ので, その正確な形状は両表面に対する溶液の濡れ性, キャ ピラリ接近距離, および液滴量に支配される。したがって, 低湿度環境下, 電極反応などによりその濃度が変化し得る溶 液を用いて，異なる仕事関数を示す試料表面上では，数十\% 程度 ${ }^{4)}$, 電極面積が変動するため, 試料電極面積を一定に保 持することは比較的難しい。このため, 示強的物理量を得る ための適用には, 液滴の濡れ面積を計測する補助機能が必要 である。しかしながら, キャピラリ先端が試料表面と非接触 であるため, 微小セルを試料表面方向に走査しやすい特徵を 持っている。

3. 1. 2 ガスケット型キャピラリ微小セル

この型では, 図 $1 \mathrm{~b}$ に示すようにキャピラリ先端は試料 表面に接触しており, 微小セルはその接触部内部に形成され る5),88,9)。キャピラリ先端と試料表面の間から電解質溶液の漏 れを防ぐために，キャピラリ先端にはシリコーンゴムなどの 弾性体がガスケットとして塗布されている。ガスケットはそ れを押し付ける荷重に依存して変形するが, 試料電極の直径 は変形したガスケットの内径に等しいので, 電極面積の再現 が容易である。また，メニスカス型では要件とされた電解質 溶液の試料表面漏れ性を考慮する必要はない。ガスケットと 試料表面の間に溶液が入り込むと試料表面ですき間腐食を発
生することがあるので, 目的にもよるが，精密な測定のため にはガスケットの押し付け荷重を繊細に制御する必要がある。 さらに, 微小セルに溶液を導入する際, 試料電極上に気泡を 残さぬようにガス抜きに配慮する必要がある。これらの操作 は個々の試料表面部位に微小セルを形成する都度行わねばな らず，微小セルの走査はメニスカス型に比べて繁雑となる。

3. 1.3 フロー型キャピラリ微小セル

キャピラリ微小セルの対極と試料電極の間が一定であると き, 両電極の間を占める溶液体積は, 用いるキャピラリの内 径の自乗にほぼ依存するので, 微小セルであるほど溶液体積 は小さくなる。目的とする電極反応が金属の電析や溶解など でその反応量が大きな場合, 溶液の濃度変化は著しくなる。 この問題は, 新鮮な電解質溶液を微小セル内へ供給し, 使用 済み溶液を微小セルから回収する二つチャンネルを持つキャ ピラリの導入により回避される。Lohrengel らは, 断面が $\theta$ 型のガラスキャピラリを用いたガスケット型キャピラリ微小 セルを開発し, 各々のチャンネルで溶液の供給と排出を可能 としている10)。また, Fushimiらは2つの異径キャピラリを 組み合わせて同軸構造とし, 溶液を内側から供給, 外側で排 出するメニスカス型キャピラリ微小セルを開発した ${ }^{11)}$ 。両者 ともに電解質溶液は継続して交換されるので, 溶液濃度の時 間変化はない。また, セル内の流束に対応して電極近傍の物 質移動が加速され, 反応速度が増加する ${ }^{12), 13)}$ 。

\section{2 キャピラリと電極}

上述のいずれの型の微小セルにおいても, 試料電極は電解 質溶液と接触する試料表面の微小領域に等しく, その直径は $1 \mu \mathrm{m}$ 以下まで小さくできる ${ }^{8)}$ が, 評価する試料電極領域に 応じた内径のキャピラリ先端および対極と参照電極を用意す る必要があり, セルが微小になるほどそれらの作製と取り扱 いは難しくなる。

マイクロピペットの交換ピペットチップであるガラス製 キャピラリは, その外径が数 $\mathrm{mm}$ あるが, 加熱・延伸・切 断・研磨操作によりサブ $\mu \mathrm{m}$ の開口径を持つキャピラリ先 端を得ることができるので, 頻繁に用いられる。その絞り込 んだ加工部は, 後述するように対極や参照電極の配置を考慮 すると, 可能な限り短いことが好ましい。同じ幾何学形状を 再現よく得るために, 電気生理学のパッチクランプ法で用い られるキャピラリープラーや光学顕微鏡付き研磨機などが使 用される。また，内径数十 $\mu \mathrm{m}$ 以上あるが，ガスクロマト グラフ用石英カラムなどもキャピラリとして使うことができ る。

三電極電気化学セルを構成する際, 対極および参照電極は, 常に溶液が接するキャピラリ内部に配置される必要がある。 その配置法には, 種々が提案されている(図 2 参照)が, セル のサイズ，あるいはセルを作製する際の簡便性，適用目的の ために選択される。液抵抗 $R_{\mathrm{s} 01}$ は電極間距離に比例する一 方, キャピラリ内側の断面積に反比例するので, 対極は試料 電極に可能な限り近接して配置するのが好ましい。不透明な ため取り扱いが面倒であるが，金属製小径管，あるいは内側 に金属などを蒸着したガラスキャピラリの導電部位を対極と する場合, 液抵抗を小さくすることができる。しかしながら， 本法で取り扱う電流は電極少イズがゆえに普通微弱である。 
ある程度液抵抗が大きくても電解電流が微小であるとき， $I R_{\mathrm{s} 01}$ 降下は比較的小さいので, $I R_{\mathrm{s} 01}$ 補正などの配慮は必要 ない。

参照電極は，通常，対極より複雑な構造である。キャピラ リ内部の空間は狭小であることから，IR $R_{\mathrm{s} 01}$ 降下が比較的小 さい場合，参照電極は対極よりも試料電極から離れて配置さ れる。しかし, フロー型セルで比較的大きな電流が流れ, $I R_{\mathrm{S} 01}$ 降下が無視できない場合, 試料-参照電極間距離をより 小さくする，あるいは電位を $I R_{\mathrm{s} 11}$ 補正するなどの配慮が必 要である。液絡を備えた参照電極を利用するために, 特に微

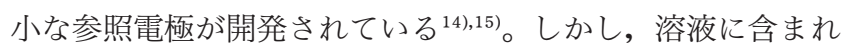
る支持電解質アニオン (またはカチオン)を含む半電極反応を 利用した参照電極であれば，液絡を設けることなくキャピラ リ内に設置可能である(たとえば， $\mathrm{Cl}^{-}$イオンを含む電解質 水溶液の場合には, $\mathrm{AgCl}$ を被覆した $\mathrm{Ag}$ 細線をそのまま用 いることができる)。また, 白金などの不活性電極材料の細 線を擬似参照電極として用いる場合も多い。

いずれの配置においても，対極および参照電極のサイズは 有限である。したがって，より微小なセルの作製にはそのセ ルに応じた微小な対極あるいは参照電極を用意するための精 密な作製技術が要求される。

\section{3 測定と特徵}

本法は, 電気化学測定の種類を選ばない。自然電位測定, 定電位分極，動電位分極，サイクリックボルタンメトリー, 分極抵抗法，交流インピーダンス法，交流重畳ボルタンメト リー，対流ボルタンメトリーなぞ通常のマクロサイズの電極 (a)

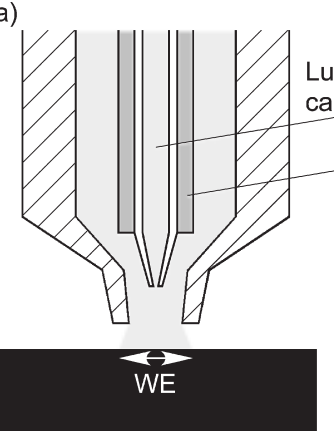

(b)

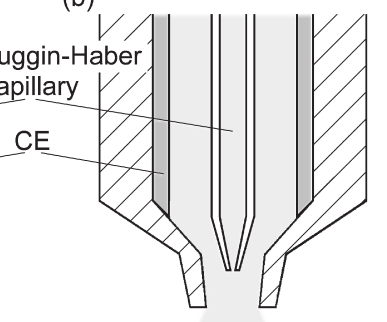

(c)

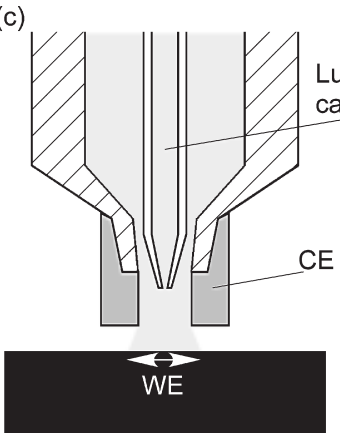

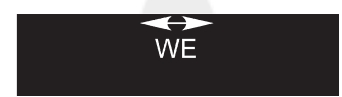

(d)

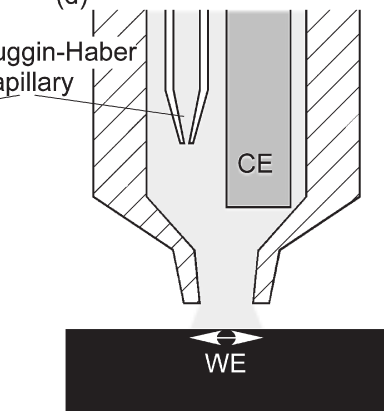

図 2 キャピラリ型微小セル内の電極配置例。(a) LugginHaber 管外側，（b）キャピラリー内側に被覆した導電体, （c）金属管などの導電体を対極に利用する場合，(d) Luggin-Haber 管と対極を別々にキャピラリー内に挿入す る場合

を用いて行うことができる電気化学測定法のすべてに適用可 能である。本法の試料電極面積は微小であるため, 供試する 試料自体を節約できる他, 複雑な構造物の微小部の局部測定 に可能である。これらは, 高価あるいは希少な試料の電気化 学評価にも本法が高い適用性を有していることを意味する。

局部試料表面の評価のため, 本法は通常, 光学顕微鏡や CCD カメラなどの光学系と組み合わせて用いられる。図 3 にその適用例9),16) を示す。キャピラリ微小セルは, 他の対物 レンズと同じくレボルバに装着されており, 試料金属組織の 特定部位にキャピラリ微小セルを設置することができ, 特定 部位の微小電気化学評価が実現できる一方, その逆の測定操 作も可能になっている。光学測定以外の表面観察法, たとえ ば電子線後方散乱回折 $\left.(\mathrm{EBSD})^{17}\right)$ は, 多結晶試料表面上の 個々の単結晶面方位を同定するので, 最近, 特に良く用いら れている。また, 微小セルを構成するガラスキャピラリを可 視 /紫外光の光路として活用すると ${ }^{4)}$, 試料微小部の光電気 化学特性の評価も実現可能である。一方, 比較的大きな内径 のキャピラリ内部に微小擦動子を配置することにより微小部 の摩擦試験を併用した電気化学測定を行うことも可能である。 この手法は，ステンレス鋼 ${ }^{18), 19)}$ および生体材料 (Ti $6 \mathrm{Al} 4 \mathrm{~V}$ 合金 ${ }^{20)}, \mathrm{CoCrMo}$ 合金 $\left.{ }^{21)}\right)$ のトライボコロージョンのその場 評価に適用されている。フロー型のキャピラリ微小セルの場 合には, セルを流れ出た反応液を分光学測定器に送り込むこ とにより, 可視 /紫外分光などの化学分析も実現されてお

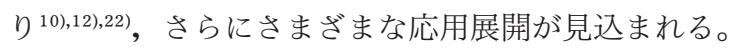

\section{4. 適 用例}

\section{1 局部表面の微小電気化学評価}

金属材料表面の不均一因子, 特に介在物は, 局部腐食の発 生起点とされており，その電気化学的挙動は耐食性を論じる 上で重要である。代表長さ数十 $\mu \mathrm{m}$ 以下の不均一因子の電 気化学的挙動の把握を目的として, 特にガスケット型のキャ ピラリ微小セル法が良く用いられている。Böhni らは, 304 ステンレス鋼の微小領域上で動電位アノード分極 ${ }^{5), 8}$ および

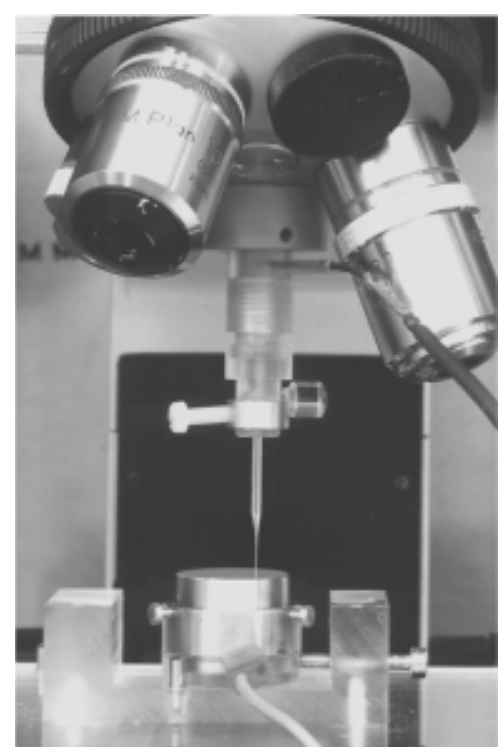

図 3 光学顕微鏡に組み込んだキャピラリ型微小セルの例 ${ }^{9), 16)}$ 
定電位分極 ${ }^{9)} し ， 孔$ 食が鋼中の MnS 介在物を含む領域で優 先的に生じることを確認した。また，Perren らは 2 相ステ ンレス鋼に適用し，単結晶面の耐孔食係数 PREN と腐食挙 動の間に良好な相関が成り立つこと，およびオーステナイト 相中の Cr 预よび Mo 欠乏領域で耐食性が低下することを報 告している ${ }^{23), 24)}$ 。他の研究グループによっても $409 \mathrm{~L}^{25)}, 304$ L-RES ${ }^{26)}$, 303 ステンレス鋼 ${ }^{27)}$ の孔食発生挙動, また圧延 $\mathrm{Al} 0.5 \mathrm{Mg}$ 合 金 ${ }^{28)}$, AA 7075 合金 ${ }^{29)}$ の脱不働態化挙動, PVD 被覆した AZ 91 合金の欠陥部 ${ }^{30)}$ における電気化学挙動 がキャピラリ微小セル法を用いて検討されている。図4 に Muto らによって測定されたアノード分極曲線27) を示す。微 小セルで測定した基材マトリックス (specimen I) と MnS 介 在物上 (specimen II) 局所表面の溶解にともなうアノード電 流と電流が急激に増加する電位に違いが見られ，後者におい て $\mathrm{MnS} /$ マトリックス境界部におけるマトリックスの優先溶 解が関係していることが指摘された。他方, Lohrengel らは $\mathrm{Fe}_{3} \mathrm{C} \gg \mathrm{Ni}(\mathrm{OH})_{2}$ の単一微小粒子 $(10 \mu \mathrm{m} \phi \text { 以下 })^{31)}$, ある いは $\mathrm{p}-\mathrm{Si}$ ウエハ ${ }^{32)}$ の電気化学測定にも適用している。

\section{2 表面特性の分布}

金属組織中の介在物以外の因子，特に多結晶体試料である 場合の結晶面方位や粒界は，材料表面の局部特性に影響を与 えるものと考えられる。この評価にはキャピラリ微小セルを 試料材料表面上で走査して注目する物理量の座標に対する分 布を得る手段が便利である。この目的のためにはメニスカス 型キャピラリ微小セルが主に用いられている。Hassel と Lohrengel は，インピーダンス測定などにより $\mathrm{Al}$ などバル ブ金属表面局部に形成したアノード酸化皮膜の膜厚分布を評 価可能であることを見いだした7)。これにもとづき，Lohrengel らは, $\mathrm{Zr}^{33), 34)}, \mathrm{Hf}^{35), 36)}, \mathrm{Nb}^{34)}, \mathrm{Ta}^{34)}, \mathrm{Zn}^{37)}$ 表面上 に形成するアノード酸化皮膜の面方位依存性を調べた。図 5

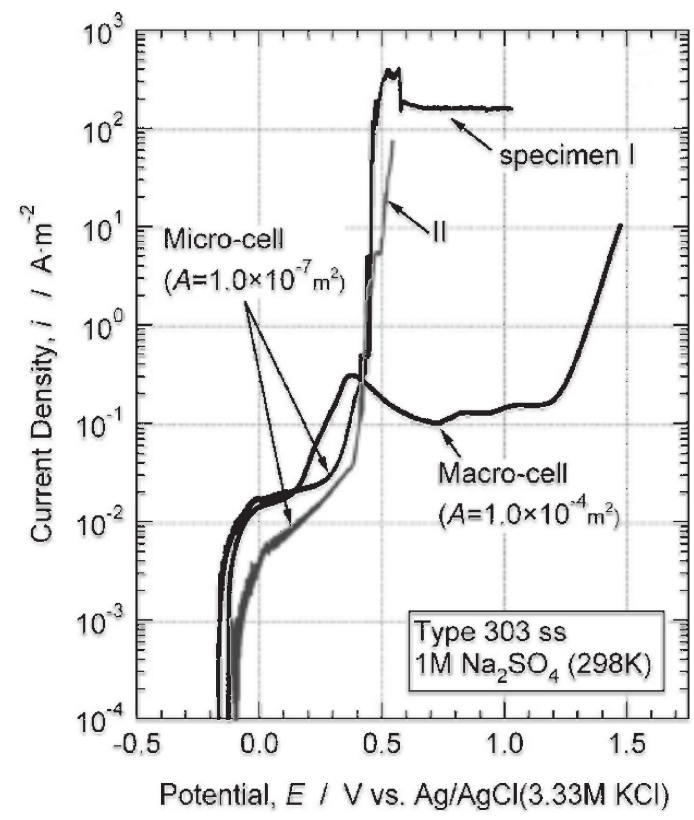

図4 $1 \mathrm{M} \mathrm{Na}_{2} \mathrm{SO}_{4}$ 水溶液中, 巨視的セルおよび微小セルによっ て測定した 303 ステンレス鋼のアノード分極曲線 試料 I：基材マトリックス上，試料 II ：MnS 介在物 /マ トリックス上 ${ }^{27)}$
にその一例 ${ }^{35)}$ を示す。hcp 構造をとる Hf 多結晶体表面上に 形成する酸化皮膜の容量密度が結晶毎に異なっている様子が

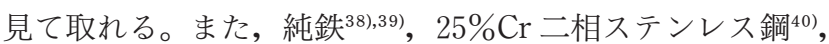
$\mathrm{Fe} 7.5 \mathrm{Al} 7 \mathrm{Cr}^{41)}$, $73 \mathrm{Pd} 13.5 \mathrm{Cu}$ 合金 ${ }^{42)}$ の異方性腐食挙動が 調べられている。

\section{3 局所溶解反応への応用}

フロー型のキャピラリ微小セルを使用する場合, 電極反応 によってセル溶液の濃度が変化することがないので, 微小電 極反応を定常的に継続することが可能である。Lohrengel ら は, 本法を鉄10),22),43) 45) や $\mathrm{TiC} / \mathrm{TiN}$ 超硬合金 ${ }^{46)}$ の電解微細 加工に適用している。

\section{4 傾斜組成材料断面の評価}

材料表面に機能性を持たせるためにさまざまな表面処理が 行われる。熱処理や加工を含めて, 材料の横方向あるいは深 さ方向に物理量の分布を持つ試料の微小電気化学測定に, 本 法は最適である。たとえば，自動車のラジエータに用いられ るアルミニウム合金はろう材 (b. f.) / 心材 /犠材 (s. a.)のク ラッド構造を成し, ろう付け熱処理される。犠材の犠牲防食 効果は, 深さ方向に劣化する腐食電位として評価することが できるが，研削と自然電位測定を繰り返さねばならず，精密 な腐食電位分布を得るのは時間と手間が必要であった。フ ロー型キャピラリ微小セルの適用したところ，図 6 のように， この板材断面の高精度な腐食電位分布を短時間で得ることが できた ${ }^{11)}$ 。本手法は，溶接した HAZ の耐食性評価にも用い られている47),48)。

\section{5 微細加工への応用}

微小電気化学法としてキャピラリ微小セル法は, 試料の局 部評価のみならず，さまざまな微細構造物の電解加工に適用 可能である。Lohrengel らは, 透明電極上に蒸着した $\mathrm{Al}$ を 局所的にアノード酸化し, 表面プラズモン共鳴を誘起する微 小酸化物構造体の作製を試みている(4),36),49)。また， Ti 表面 に微小アノード酸化皮膜パターンを描写する試みもなされて いる ${ }^{50), 51)}$ 。他方，Sakairi らは，フロー型の同軸キャピラリ セルを用いて $\mathrm{Cu}$ や $\mathrm{Ni}$ の電析を行っている ${ }^{52)}$ 。図 7 はその 一例であり，電析速度とキャピラリセルの移動速度を同期さ せることにより，Cu を電析直径 $100 \mu \mathrm{m}$ でアスペクト比 100 を越える特異形状微小構造物や $\mathrm{T}$ 字型微小構造物など, LIGA 法では作製困難な微細加工に成功している。

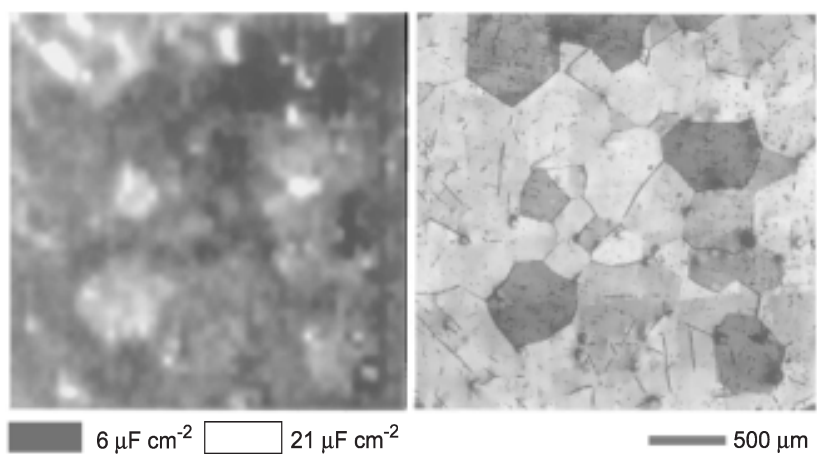

図 $5 \mathrm{Hf}$ 多結晶体表面の容量密度分布図（左）とその測定領域 の光学顕微鏡像 $(\text { 右 })^{35}$ 


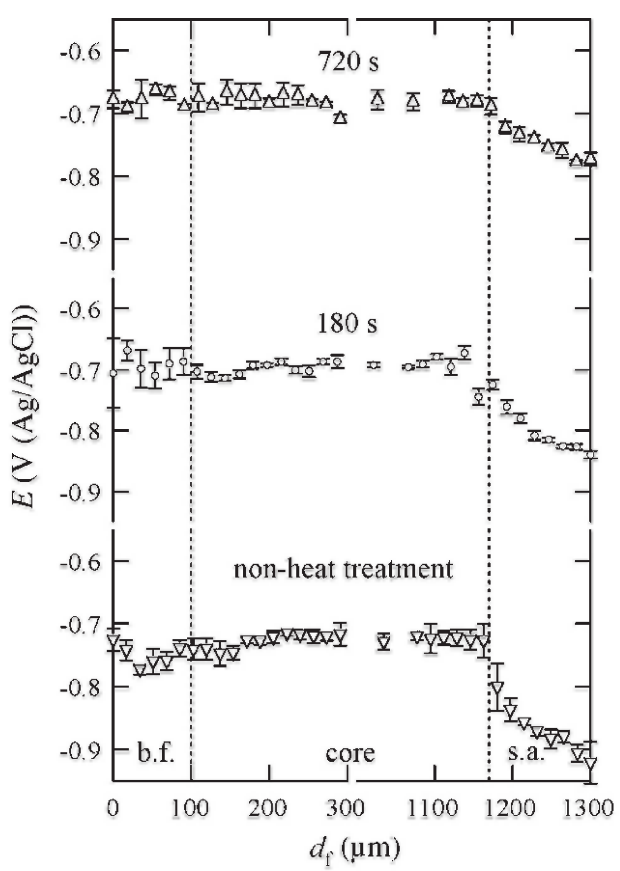

図 6 自動車ラジエータ用アルミニウム合金クラッド材断面深さ $d_{\mathrm{f}}$ 方向の腐食電位プロファイル

ろう付け熱処理時間により犠材（s. a.）と心材との電位 差が小さくなっている11)

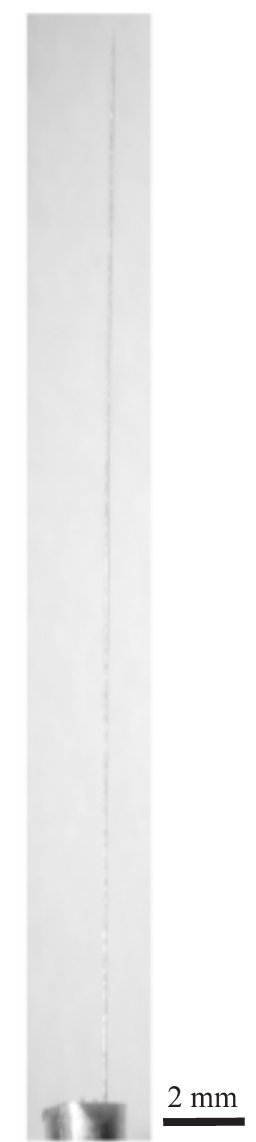

図７フロー型キャピラリ微小セルを用いてめっきにより作製し た微小 $\mathrm{Cu}$ 構造物

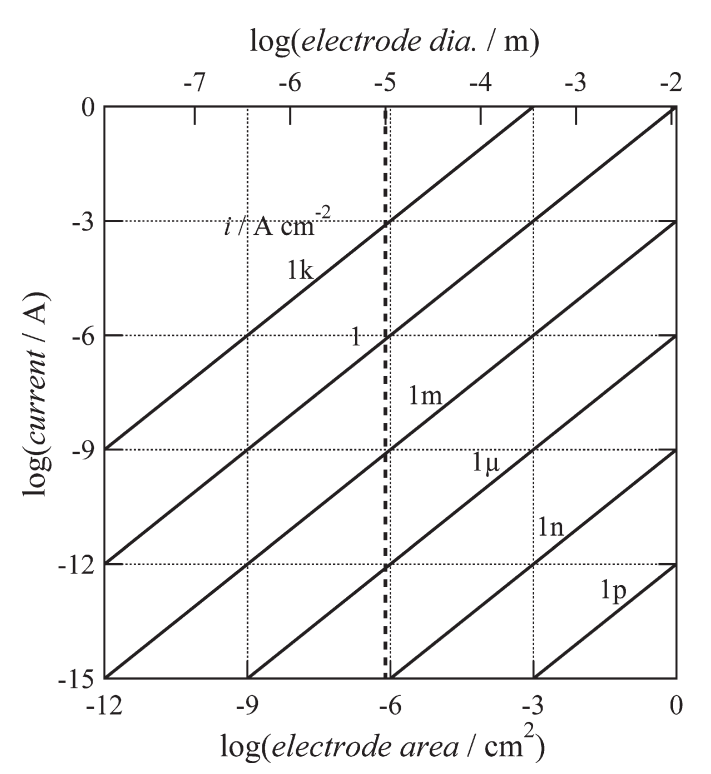

図 8 円盤電極に流れる電流と電極面積，および電極直径の関係

\section{5。適用の限界}

キャピラリ微小セル法と組み合わせるポテンショスタット の電流検出分解能は, 本法の測定限界を決定する主要因子で ある。図 8 に電流と電極面積抒よび円盤電極を仮定した時の 電極直径の両対数関係を図示する ${ }^{53)}$ 。検出分解能 $1 \mathrm{nA}$ を下 限とする汎用のポテンショスタットでは, 先端直径 $10 \mu \mathrm{m}$ のキャピラリを用いた場合, 電析反応や溶解反応など $1 \mathrm{~mA}$ $\mathrm{cm}^{-2}$ 相当の比較的大きな電流密度を要する電極反応までし か対応できないことが見てとれよう。同じ $10 \mu \mathrm{m}$ の面分解 能で不働態保持電流など $1 \mu \mathrm{A} \mathrm{cm} \mathrm{cm}^{-2}$ 相当の電流密度で起こ る電極反応を検出するには, $1 \mathrm{pA}$ の検出分解能をもつ微弱 電流用のポテンショスタットが必要になってくる。さらに, 同反応を面分解能 $1 \mu \mathrm{m}$ で検出する場合には, 検出分解能 10 fAのポテンショスタットが必要であるが，これを実現する ためには，ポテンショスタット自身はもとよりセルに接続す る配線などを含めて慎重なノイズ対策が不可欠になってくる ことは言うまでもない。しかし，これらが克服されれば，材 料表面の局部電気化学評価が極めて䋊細なレベルで実現され ることになり，評価ツールとして大いに役立つことであろう。

(2008-8-20 受理)

\section{文献}

1) H. S. Isaacs and B. Vyas; Electrochemical Corrosion Testing, p. 3 (ASTM, STP 727, 1981).

2) M. Sugawara and A. Hirano ; BUNSEKI KAGAKU, 51, 1121 (2002) (in Japanese).

3 ) M. M. Lohrengel ; Corros. Eng. Sci. Tech., 39, 53 (2004).

4 ) M. M. Lohrengel, A. Moehring and M. Pilaski ; Fres. J. Anal. Chem., 367, 334 (2000).

5 ) H. Böhni, T. Suter and A. Schreyer ; Electrochim. Acta, 10, 1361 (1995).

6 ) M. M. Lohrengel ; Electrochim. Acta, 42, 3265 (1997).

7 ) A. W. Hassel and M. M. Lohrengel ; Electrochim. Acta, 42, 3327 (1997). 
8 ) T. Suter and H. Böhni ; Electrochim. Acta, 42, 3275 (1997).

9) T. Suter and H. Böhni ; Electrochim. Acta, 43, 2843 (1998).

10) M. M. Lohrengel, I. Klüppel, C. Rosenkranz, H. Bettermann and J. W. Schultze ; Electrochim. Acta, 48, 3203 (2003).

11) K. Fushimi, S. Yamamoto, R. Ozaki and H. Habazaki ; Electrochim. Acta, 53, 2529 (2008).

12) M. M. Lohrengel, C. Rosenkranz, I. Klüppel, A. Moehring, H. Bettermann, B. Van den Bossche and J. Deconinck; Electrochim. Acta, 49, 2863 (2004).

13) K. Fushimi, S. Yamamoto, H. Habazaki and H. Konno ; submitted.

14) A. W. Hassel, K. Fushimi and M. Seo ; Electrochem. Commu., 7, 180 (1999).

15) K. A. Lill and A. W. Hassel ; J. Solid State Electrochem., 10, 941 (2006).

16) H. Boehni, T. Suter and F. Assi ; Surf. Coat. Tech., 130, 80 (2000).

17) M. Pilaski, T. Hamelmann, A. Moehring and M. M. Lohrengel ; Electrochim. Acta, 47, 2127 (2002).

18) F. Assi and H. Böhni ; Wear, 233-235, 505 (1999).

19) H. Böhni, T. Suter and F. Assi ; Surf. Coat. Tech., 130, 80 (2000).

20) F. Contu, B. Elsener and H. Böhni ; Electrochim. Acta, 50, 33 (2004).

21) F. Contu, B. Elsener and H. Böhni ; Corros. Sci., 47, 1863 (2005).

22) M. M. Lohrengel and C. Rosenkranz ; Corros. Sci., 47, 785 (2005).

23) R. A. Perren, T. A. Suter, P. J. Uggowitzer, L. Weber, R. Magdowski, H. Böhni and M. O. Speidel ; Corros. Sci., 43, 707 (2001)

24) R. A. Perren, T. Suter, C. Solenthaler, G. Gullo, P. J. Uggowitzer, H. Böhni and M. O. Speidel ; Corros. Sci., 43, 727 (2001).

25) H. Y. Ha, C. J. Park and H. S. Kwon ; Corros. Sci., 49, 1266 (2007)

26) V. Vignal, H. Krawiec, O. Heintz and R. Oltra ; Electrochim. Acta, 52, 4994 (2007).

27) I. Muto, Y. Izumiyama and N. Hara ; J. Electrochem. Soc., 154, C 439 (2007).

28) F. Andreatta, M. M. Lohrengel, H. Terryn and J. H. W. de Wit ; Electrochim. Acta, 48, 3239 (2003).

29) G. Buytaert, Premendra, J. W. H. de Wit, L. Katgerman, B. Kernig, H. J. Brinkman and H. Terryn ; Surf. Coat. Tech., 201, 4553 (2007).

30) H. Hoche, C. Rosenkranz, A. Delp, M. M. Lohrengel, E. Bronszeit and C. Berger ; Surf. Sci. Tech., 193, 178 (2005).
31) T. Hamelmann and M. M. Lohrengel ; Electrochim. Acta, 47, 117 (2001).

32) A. G. Muñoz, A. Moehring and M. M. Lohrengel ; Electrochim. Acta, 47, 2751 (2002).

33) A. Moehring and M. M. Lohrengel ; Passivity of Metals and Semiconductors, PV 99-42, p. 114 (The Electrochemical Society, 2000).

34) J. W. Schultze, M. Pilaski, M. M. Lohrengel and U. König ; Faraday Discuss., 121, 211 (2002).

35) M. M. Lohrengel, A. Moehring and M. Pilaski ; Electrochim. Acta, 47, 137 (2001).

36) M. Pilaski, T. Hamelmann, A. Moehring and M. M. Lohrengel ; Electrochim. Acta, 47, 2127 (2002).

37) C. J. Park, M. M. Lohrengel, T. Hamelmann, M. Pilaski and H. S. Kwon ; Electrochim. Acta, 47, 3395 (2002).

38) A. Schreiber, J. W. Schultze, M. M. Lohrengel, F. Kármán and E. Kálmán ; Electrochim. Acta, 51, 2625 (2006).

39) A. Schreiber, C. Rosenkranz and M. M. Lohrengel ; Electrochim. Acta, 52, 7738 (2007).

40) C.-J. Park, H.-S. Kwon and M. M. Lohrengel ; Mater. Sci. Eng. A, 372, 180 (2004).

41) K. A. Lill, A. W. Hassel, G. Frommeyer and M. Stratmann ; Electrochim. Acta, 51, 978 (2005).

42) G. Hildebrand, A. Schreiber, M. Lohrengel, R. Strietzel and K. Liefeith ; Corros. Sci., 48, 3629 (2006).

43) M. M. Lohrengel ; Mater. Manufact. Proc., 20, 1 (2005).

44) C. Rosenkranz, M. M. Lohrengel and J. W. Schultze ; Electrochim. Acta, 50, 2009 (2005).

45) M. M. Lohrengel, C. Rosenkranz and D. Rohrbeck ; Microchim. Acta, 156, 163 (2007).

46) B. Walther, J. Schilm, A. Michaelis and M. M. Lohrengel ; Electrochim. Acta, 52, 7732 (2007).

47) T. Nakayama, M. Sakairi, K. Fushimi and S. Hashizume ; Proc. of Eurocorr 2007, 1130.pdf (2007).

48) S. Hashizume, T. Nakayama, M. Sakairi and K. Fushimi ; Proc. of NACE 2008, No. 08102 (2008).

49) M. Pilaski and M. M. Lohrengel ; Electrochim. Acta, 48, 1309 (2003).

50) A. W. Hassel, K. Fushimi, T. Okawa and M. Seo ; Localized In Situ Methods for Investigating Electrochemical Interfaces, PV 99-28, p. 166 (The Electrochemical Society, 1999).

51) A. I. Mardare, A. D. Wieck and A. W. Hassel ; Electrochim. Acta, 52, 7865 (2007).

52) M. Sakairi, F. Sato, Y. Goto, K. Fushimi, T. Kikuchi and H. Takahashi ; Electrochim. Acta, accepted.

53) M. M. Lohrengel, A. Moehring and M. Pilaski ; Electrochim. Acta, 47, 137 (2001). 